\title{
The Effect of Using Web-Cam Chat on the Undergraduate EFL Students' Pragmatic Competence
}

\author{
Ahmad Mousa Bataineh ${ }^{1, *}$ \& Nadhim Obaid Hussein ${ }^{1}$ \\ ${ }^{1}$ Dept. of Curricula and Instruction, Al al Bayt Universty, Mafraq, PO Box 130040, Postal \\ Code 25113, Jordan \\ *Corresponding author: Dept. of Curricula and Instruction, Al al Bayt Universty, Mafraq, \\ PO Box 130040, Postal Code 25113, Jordan. Tel: 962-796-400-687 E-mail: \\ amab88@yahoo.com
}

Received: February 3, 2015 Accepted: June 22, 2015 Published: June 29, 2015

doi:10.5296/ije.v7i2.7929 URL: http://dx.doi.org/10.5296/ije.v7i2.7929

\begin{abstract}
This study aimed to investigate the effect of using web-cam chat on developing of the pragmatic aspects of language by college-level English as foreign language (EFL) learners in Jordan. A quantitative approach was applied to determine first, whether the use of web-cam chats had a positive effect on EFL learners' pragmatic competence. Second, the effect of presenting pragmatic through two delivery systems face-to-face, in-class activities and computer-mediated communication (CMC) via web-cam chats i.e. Facebook and Skype was investigated in this study. The sample of the study consisted of thirty-two undergraduate students who made up two intact classes in a "Conversation Skills course, which call Penguin Functional English by Peter Watcyn-J0nes .Code N 1302109" at AL al-Bayt University in Jordan, during the second semester of the academic year 2013/2014. The students were interviewed in order to know their actual levels in the pragmatic aspects of English before starting the experiment. The sample was divided into two groups; the control group (15 students) was taught the course content using the regular communicative method through which students received instructor-led lessons from the textbook, while group two, the experimental (17 students) was taught using web-cam chat. After conducting the activities, a post test was administered. Scores were tabulated and prepared for statistical analysis. The results showed that web-cam chat had a positive impact on the EFL learners' pragmatic competence. Learners who studied via web-cam chat performed better on the pragmatic aspects of English post-test than those who did not. The findings also indicated that technology can be a valuable tool for delivering pragmatic instruction. Moreover, the findings of the study revealed that students acquired the speaking and listening skills in web-cam chat more efficiently and effectively than in the regular communicative method.
\end{abstract}

Keywords: Web-Cam Chat, Pragmatic Competence, computer-mediated communication 


\section{Introduction}

Nowadays, information revolution is bringing people of different backgrounds from around the world into a global information superhighway. Technology provides a global platform connecting thousands of networks around the world. According to Means \& Rochelle (2010), information and communication technology (ICT) has been used in schools since the 1980s, but the advent of the World Wide Web, along with increases in computing power at low cost and portable forms have made use of ICT much more prominent for learning. Moreover, ICT is being used to support teaching, learning and assessment. Current technology trends with the potential to further change learning practices include the increasing availability of open-source course content on the Internet, and the rise of collaborative user-generated content are likely to make ICT an increasingly important factor in learning.

In addition, the Internet access opens up new opportunities for education to go online. One aspect of using the Internet in education is using audio and visual chat. Schavo (2011) pointed out that the revolution in technology has given rise to chat rooms and discussion rooms. The information technology sector has completely changed the outlook of human communication with Skype, videoconferencing, and instant messaging. Moreover, the Internet audio-visual chat enables students to participate in group discussions with others to develop their pragmatic aspects of language, and English language skills, including the productive skills (speaking and writing).

This present study investigates the effect of web-cam chat on the undergraduate EFL students' four language skills besides its effect on their pragmatic competence that was investigated in this study.

\subsection{Background of the Study and Statement of the Problem}

In the previous decades, researchers tried to formulate models of communicative language proficiency and identify the components of communicative competence (Canale and Swain, 1980; Bachman and Plamer, 1982; and Bachman, 1990). Moreover, Canale and Swain proposed the communicative competence model, which consists of three main components: Grammatical competence, sociolinguistic competence, and strategic competence. Grammatical competence refers to the knowledge that leads to mastery of the language itself. Sociolinguistic competence addresses the extent to which utterances are produced and understood appropriately in different sociolinguistic contexts. Strategic competence is the mastery of verbal and non-verbal communication strategies that could be implemented to compensate for breakdowns in communication resulting from limiting conditions in actual communication or insufficient competence in one or more of the other areas of communicative competence, and to enhance communication effectiveness.

A decade later, (Canale and Swain, 1980) proposed the language competence model, which consists of two main categories: Organizational competence and pragmatic competence. Organizational competence refers to knowledge of linguistic units and the rules for forming structured sentences (grammatical competence) and the knowledge of using discourse in context (textual competence). Pragmatic competence consists of illocutionary competence, 
which means knowledge of speech acts and speech functions, and sociolinguistic competence, or the ability to use language in socio-cultural contexts. These elements demonstrate that to be communicatively competent, an individual must gain not only knowledge of linguistic forms, but also knowledge of the appropriate use of language in communicative contexts.

Pragmatic competence is not a piece of knowledge additional to the learners' existing grammatical knowledge, but it is an organic part of the learners' communicative competence (Kasper, 1997). This means that pragmatic does not focus on grammatical knowledge, but it focuses on the meaning of learners' language use in the acts of communication. Moreover, it focuses on helping learners to create meaning rather than develop perfectly grammatical structure. More obviously, according to Crystal (1997: 301) "pragmatics is the study of language from the point of view of users, especially of the choices they make, the constraints they encounter in using language in social interaction and the effects their use of language have on other participants in the act of communication." This means that it uses language from view point of users, and enables EFL learners to communicate efficiently and effectively.

In addition, the main concern of teachers and teacher trainers is not to teach about language, but to develop learners' abilities to make them capable of using the language for a variety of communicative purposes (Bataineh, 2014). Moreover, there is a difference between teaching about the language and communicating in the language. From my own experience and an experience of others who were specialized in TEFL, one great problem in foreign languages classes, teaching about the language itself alone makes the learners incapable of using the language for communication.

Moreover, pragmatics has been defined in various ways. According to Yule-G. (2000:3) "Pragmatics refers to the study of meaning in interaction or meaning in context, exploring how linguistic utterances could be interpreted differently as a result of different contextual forces and communicative goals". He defined pragmatics as the study of speakers' meaning. The focus is upon the interpretation of what people mean by their utterances rather than what the phrases in the utterances mean by themselves. This means the meaning of speaker is necessarily bound to contextual meaning and how a particular context influences what is uttered. The context comprises the addressee, the place, the time and other circumstances.

Furthermore, research in pragmatic competence has repeatedly proven that even proficient speakers of English often lack necessary pragmatic competence (Bataineh, 2014). That is, they are not aware of the social, cultural, and discourse conventions that have to be followed in various situations. Research has also been conducted on the disparity between grammatical and pragmatic competence. However, relatively less attention has been paid to how classroom-based instruction can contribute to the foreign language learners' pragmatic development.

Several studies have examined the effect of instructional intervention in the development of pragmatic knowledge. The topics included pragmatic fluency (House, 1996), pragmatic routines (Tateyama et al.,1997; Tateyama, 2001 and Wildner-Bassett, 1994), conversation closing (Bardolvi-Harlig et al., 1991), apologies ( Eslami et al., 2004; Olshtain \& Cohen, 
1990), compliments (Billmyer, 1990 and Rose \& Kwai-fun, 2001), conversation (Bouton, 1994 and Kubota, 1995) and requests (Eslami et al., 2004); Rose, (1994), and Fukuya, (1998). Results from most of these studies indicated the positive impact on language learners' pragmatic knowledge, supporting the belief that the pragmatic ability can be enhanced or developed through systematic classroom activities. Moreover, studies conducted by Eslami (2005), Kasper (1997), Rose (1994), and Tateyama et al. (1997) suggested that pragmatic features can be acquired through explicit instruction. This means that explicit instruction plays a very important role to improve EFL learners' pragmatic competence.

D'Ambra et al. (1998) claimed that e-mail, web-cam users evaluated the communication richness of $\mathrm{CMC}$ systems by their capacity to transmit social information traditionally transmitted by face-to-face or/and phone communication. They found that voice-mail or web-cam are appreciated because such systems have the capacity to transmit social information which is absent in classical e-mail communication. Social information is scarce in $\mathrm{CMC}$; any information transmitted has a more powerful impact on the receiver than with other communication modes where such information is transmitted more fully. This means that e-mail or web-cam are very important in the process of language learning. With the help of these instructional technologies EFL learners can communicate with people in most parts of the world very cheaply and quickly. Moreover, they provide EFL learners with rich context to reflect on native and target language cultural practices, perspectives, and products.

Chun (1998) suggested that synchronous CMC could elicit more learner participation as well as better quality of language in terms of pragmatic development than that found in face-to-face interaction in that participants are allowed to have affordable time to process input, monitor and output via a written-based medium. This means that CMC enables EFL learner who desperately need more pragmatic competence, provides an opportunity to use language in classroom. The use of CMC tools both inside and outside of the classroom certainly can benefit the learners and develop their communicative competence to a certain extent. In addition, CMC allows learners to interact in an authentic context with native speakers without being restricted by location.

The problem of the study stems from the researchers' own experience and observations inside the foreign language class as a student and a teacher, EFL students may find difficulty in using the English language expressively and effectively. His own experience has also showed that many students are at most linguistically competent, but they cannot convert their linguistic knowledge into actual practice, which might be due to the fact that our EFL students are rarely exposed to authentic audio-visual contexts in their FL courses, although language use is more important than language usage. This may not be achieved without having an actual exposure to authentic language via technology.

English language may be difficult to learn because the learners may not have real-life situation to practice the language. Learners do not practice using English, and classroom environments is at most not well-prepared for interaction. This study focuses on using chat modes (web-cam) for developing university EFL learners' pragmatic competence. This may create situations and better environment for learners to communicate with each other. 
The Purpose of the study is to add the scholarly literature the impact of using web-cam chat on adult EFL learners' pragmatic development. It sought to examine whether EFL learners' pragmatic competence can be enhanced by using web-cam chat. This study adopted well known assess pragmatic competence in terms of five components (discourse function, speech acts, speech function, degree of formality, and politeness), and tried to find out which component of pragmatic competence is the easiest, and the most difficult component to develop. Rose (2005) pointed out that the most basic question that studies the effect of CMC on pragmatics is whether a particular area of pragmatics is teachable. Furthermore, this study integrated technology as one of the delivery systems to determine whether CMC can serve as a potential channel to deliver pragmatics instruction to EFL learners. This study also sought to determine language learners' perceptions of learning pragmatics through on-line communication.

This study is significant in the sense that it to contribute to the existing literature on pedagogical intervention in the development of EFL learners' pragmatic competence and to form approaches to second-or foreign-language instruction with theory and research on pragmatics development. This study has implications for second or foreign language educators in the areas of teaching, assessment, and syllabus design. The results of this study might further our understanding of the effectiveness of using web-cam chat on EFL learning environments. It might also help us determine the impact of face-to-face and CMC delivery systems on EFL learners' pragmatic development. English education in EFL settings has overlooked the importance of pragmatics, and the findings of this study might help language educators realize the role that pragmatics can play in language education, and how the pragmatic features of language can be developed in classrooms. The results might help instructors understand how students perceive learning pragmatics through technology, identify a suitable learning environment and conditions. It might help the teachers in finding new procedures that can create better users of the language, and decide the extent to which this mode of pragmatics instruction is applicable to EFL learners.

\subsection{Questions of the Study}

This study attempted to answer the following questions:

1. Are there any statistically significant differences between the mean scores of the experimental and control groups in performance due to the method of teaching (webcam chat CMC vs. regular communicative method)?

2. Which pragmatic aspects of language do learners develop more as a result of using web-cam chat? These aspects include (discourse function, speech acts, speech function, degrees of formality, and politeness)

3. Are there any statistically significant differences between the mean scores of the experimental and control groups in pragmatics due to skills (receptive vs. productive skills)? 


\subsection{Hypothesis of the Study}

Based on the preceding research questions, the following hypotheses are formulated:

Ho1: There are no statistically significant differences between the mean scores of the experimental and control groups in performance due to method of teaching (web-cam CMC vs. regular communicative method) at the $(\alpha \leq 0.05)$ level.

Ho2: There are no statistically significant differences between the mean scores of experimental group's mastery of each pragmatic aspect of language at the $\quad(\alpha \leq 0.05)$ level. These aspects include (discourse function, speech acts, speech functions, degrees of formality, and politeness).

Ho3: There are no statistically significant differences between the mean scores of the experimental and control groups in pragmatics due to skills (receptive vs. productive skills) at the $(\alpha \leq 0.05)$ level

\subsection{Limitations of the Study}

There are several limitations to the generalization of the results of this study:

The duration of the study was limited to a period of 8 weeks. The participants' size was small and only included a selected group of individuals (undergraduate EFL learners). The material of the study was purposefully chosen, in the sense that it was loaded heavily with pragmatic aspects of language.

\section{Review of Related Studies}

This part presents a review of related studies, which shed light on the effect of using webcam chat on the acquisition of the pragmatic aspects of language. A number of academic studies have been conducted to pave the road toward creating highly favorable learning environment.

Chun (1994) explored that synchronous CMC offered a tool to overcome some of these difficulties by reducing the pragmatic pressure of the interaction and allowing more individualized control of the learning environment. Recent research suggested that synchronous CMC could elicit more learner participation as well as better quality language in terms of pragmatic development than that found in face-to-face interaction in that participants are allowed to have affordable time to process input, monitor and output via a written-based medium.

Darhower (2002) explored social interaction of synchronous computer-mediated communication (CMC) commonly known as "chat"--as such features unfolded in real time and developed over a nine-week period in two fourth-semester college Spanish classes. The 
study invoked the socio-cultural theoretical framework and employed discourse analysis as a research tool to describe and explain outstanding features of chat room communication. Specific interactional features examined are interred subjectivity, off-task discussion, greetings and leave-takings, identity exploration and role play, humor and sarcasm, and use of the L1 (English). Through these communicative behaviors, learners appropriated the chat room environment, transforming it into a learner-centered discourse community governed by communicative autonomy and the use of language and discourse functions that go beyond those encountered in the typical L2 classroom.

By the same token, Greenfield \& Subrahanayam (2003) analyzed online discourse in a teen chat room. The study aimed to examine online chat communication as a new communicative register, understood in terms of the social and communicative conventions of language use. The authors examined how conversational coherence is established and maintained when many traditional, face-to-face communicative conventions no longer hold within social interactions. The participants were a group of native teenagers who were chatting in a teenage chat room for an unspecified period of time. The findings showed that online chat media enable participants to modify existing spoken and written communication strategies and to create new strategies to meet their communication needs.

Zha, Kelly, Park, \& Fitzgerald (2006) investigated communicative competence of students using electronic discussion boards. The study focused on the use of electronic discussion boards with elementary aged students. In addition, the purpose of the study was to investigate students' communicative competence in a computer-mediated communication environment. Scientific methods were used to analyze 956 messages posted by 28 students to the electronic discussion board during a six-week period of time. The findings revealed that students' use of written language increased through the CMC activities.

Abe (2011) investigated the connection between CMC and pragmatics instruction by measuring the effects of online chat and traditional face-to-face discussion on the acquisition of disagreement strategies in English. Japanese undergraduate EFL learners served as participants. A mixed methodology was used, and both quantitative and qualitative data from multiple sources were collected. The findings suggested that synchronous CMC is likely to be effective for pragmatic development in the Japanese EFL context.

All the studies mentioned above showed that teaching using CMC (web-cam chat) plays a major role in language learning. The present study is similar to the mentioned studies in the general aim, which is the effect of CMC on learning English language. However, this study is an attempt to investigate the effect of web-cam chat on EFL learners' pragmatic competence in general, and on the pragmatic aspects of language in particular while communicating around computers on their achievement. All studies were conducted on students at various places. This study was conducted on EFL University learners, so the need arises to investigate their receptive and productive skills under different web-cam conditions, and their effect on students' pragmatic competence. 


\section{Methodology}

\subsection{Participants of the study}

The sample of the study consisted of 32 undergraduate EFL students who were 19 years old, and registered for Conversation Skills course, which call Penguin Functional English book by Peter Watcyn-JOnes .Code N 1302109 during the second semester of the academic year 2013 / 2014 at AL al-Bayt University in Jordan. They were divided into two groups; the first group consisted of 17 students who were assigned as an experimental group, while the second group consisted of 15 students who were assigned as the control group.

\subsection{Design of the study}

A pre/post-test technique was used in this quasi-experimental study. Both groups (1 and 2) were taught the same material on the same days of the week. The control group was taught by the course teacher whereas the experimental group was taught via web-cam chat by the researchers. In addition, they were given the same test before and after the experiment to measure differences (if any) in students' achievement/performance. Group (1) that was assigned as an experimental group was taught using web-cam chat in which students interact with native speakers of English in their cultural world. Additionally, through communication with native speakers via web-cam chat, students were involved in communicative oral activities. Then, the subjects of the study had web-cam chats among each other so as to internalize what they have acquired through chatting with native speakers of English. Group (2) which was chosen as a control group was taught traditionally without using any technology. The pre-test was administered by native speakers of English on topics that are related to pragmatic aspects of the English language, and the post-test was administered in the same manner. Those examiners are teachers who teach the English language in Eqab Centre in Mafraq. To avoid subjectivity, an average score was found by the examiners for each examinee. The design of the study is stated in Table (1).

Table 1. Distribution of the Participants of the Study

\begin{tabular}{ccc}
\hline Group & Method of teaching & Number \\
\hline Experimental & web-cam chat (Skype) & 17 \\
Control & regular communicative method & 15 \\
Total & & 32 \\
\hline
\end{tabular}

\subsection{Variables of the Study}

The study has the following variables.

1-The independent variable of the study:

Teaching method, which includes:
A. Teaching pragmatic aspects by using web-cam chat, and
B. teaching pragmatic aspects by using the regular communicative method. 
2-The dependent variable is students' scores of both groups (experimental and control) on the post-test.

\subsection{Instrument of the Study}

To assess the effect of using web-cam chat on the undergraduate EFL students' pragmatic competence, students in both groups sat for a written and oral test at the beginning of the second semester of the academic year $2013 / 2014$ so as to determine their actual pragmatic knowledge before starting the experiment. The test consisted of two parts; written and oral, the written part aimed at students' ability in reading comprehension and writing skills; whereas the oral part examined students' ability in listening and speaking skills. The reading test was meant to evaluate the students' ability to comprehend different topics in different dialogues/or situations. It consisted of five questions; twenty five scores were allocated for the reading comprehension test. The writing test measured students' ability to write suitable dialogues/or situations that are pragmatically appropriate, including the ability to plan, and develop ideas. In addition, it examined the students' ability to complete sentences (recognition) as well as the use of suitable grammar and vocabulary. The writing test was a conversation on pragmatic aspects of language, where a visitor speaks about the directions to a garage station, or street. The sum of all scores for the writing test is 25 scores.

The second part of the oral test that includes the listening and speaking. The listening test was meant to evaluate the students' ability to listen to different dialogues/or situations, where students listened attentively to conversations, debates, short dialogues, and discussions that included different pragmatic aspects of language, and then, students were asked questions based on the different conversations that students listened to. It consisted of five questions; twenty five scores were allocated for the listening test. The speaking test was meant to evaluate students' ability to speak fluently about different topics on different situations and communicate orally with an acceptable level of clarity. A team of American experts asked each examinee five questions loaded with pragmatic aspects of English. These questions absolutely covered various pragmatic aspects of language. After eight weeks, the post-test was administered at the end of the study. The teacher informed the students that neither the pre-test nor the post-test would amount to their final scores in the class. The pre/post-test were based on the pragmatic information contained in the textbook. The pre-test was administered by native speakers of English on topics that were related to pragmatic aspects of language, and the post-test was administered in the same manner. An interval between the pre-test and the post-test was made for (8) weeks, which was a good period to minimize the effect of the pre-test on the results of the study. The test examined the learners' ability to function in a native community of English and communicate pragmatically appropriately in an authentic contexts. These contexts included social patterns and situations with social institutions e.g. discourse function, speech acts, speech functions, degrees of formality, and politeness.

\subsection{Instructional Treatment}

Before the experiment, the researchers explained the nature of the study and its goals for the students. Web-cam chat and its applications in learning the pragmatic aspects of language 
implicitly through chatting with native speakers of English was introduced. The students were given the opportunity to ask questions about the course/techniques and methods to be used in learning/teaching the pragmatic aspects of language. The students were divided into two groups. The first was assigned as an experimental group. They were taught by the researchers themselves at the laboratory, whereas the control group was taught by the teacher of the course in their regular class. The Skype program was installed on the computers. The researchers helped the students to sign in e-mails and give them nicknames. Then, the researchers set the scene for chatting. He helped them add each other as groups. After that, the researchers asked students to open the Skype and put the headsets on their heads and begin chatting using microphones in order to hear each other. Then, they started chatting on certain topics with native speaker.

The researchers' role was observing students' chat and communication, to provide them with advice on how to use the program, and how to solve any problem that happens while talking or listening. The researchers allowed students to communicate with native speakers to make sure that every student participates in the oral discussions. In addition, the researchers' observation was very important because some students were very interested in the web-cam chat. In this new learning experience, the researchers answered all the questions that the students had asked. Before the experimental the researchers chose any topic from the textbook and asked the students to make discussions with native speakers. After chatting with native speakers on a certain topic, students practiced chatting among themselves to internalize the pragmatic aspects they have acquired through chatting with native speakers of English. However, the control group was taught by the course teacher using regular communicative method without using any kind of technology and the students followed the regular communicative method described in the textbook. It included face-to-face interaction, brainstorming, group work, and discussions.

\subsection{Study Procedures}

This study was carried out during the second semester of the academic year 2013/2014. The following procedures were followed after the researchers got the approval of the Department of English language and Literature/AL al-Bayt University to conduct the study.

1. AL al-Bayt University was intentionally selected to conduct the study because it has an up-to-date Internet connection and suitable number of students.

2. The undergraduate students of the English language and Literature who registered in a Conversation Skills were selected as a sample of the study because they were in two sections.

3. The participants were in two sections: Section (1) was assigned as the experimental group, while section (2) was assigned as the control group. 
4. Before starting the experiment of the study, a pre-test was administered to both groups to make sure that there were no significant differences in the pragmatic competence between the experimental and control groups.

5. The researchers explained to students the nature of the study and its purposes.

6. The researchers checked Skype which is easy to use.

7. Each student logged into Skype. It needed password to allow only students in the experimental group to use it at allocated times.

8. The material was taught three times a week for each group, for a period of 8 weeks.

9. Students in all groups studied the same material.

10. A post-test was administered to the experimental and control groups after the experiment.

11. The post-test was administered by the same experts who were native speakers of English.

12. Statistical analyses were used to answer and accomplish the questions and the objectives of the study.

\section{Findings}

Table 2. Means and Standard Deviations of the Experimental and Control Groups on the Pre-Test

\begin{tabular}{ccccccc}
\hline Group & N & Mean & Std. & DF & T & Sig \\
\hline Control Group & 15 & 42.07 & 13.828 & 0.146 & 30 & 0.885 \\
Experimental Group & 17 & 42.76 & 13.155 & & & \\
\hline
\end{tabular}

Table 2 shows the absence of a statistical significant difference at the level of $(\alpha \leq 0.05)$ for the pragmatic aspects of language (discourse function, speech acts, speech function, degree of formality, and politeness) for pre-assessment due to groups. The findings showed that students' scores for both groups were almost equivalent for each variable in the pre-test before applying the experiment.

This part includes the following three sections: Findings related to the first question, findings related to the second question, and findings related to the third question.

\subsection{Findings Related to the First Question}

The first question of this study focused on if there are any significant statistical differences between the mean scores of the experimental and control groups in pragmatics due to the 
method of teaching (CMC vs. regular communicative method). To answer this question, means and standard deviations for method of teaching were calculated as stated in Table 3. To measure changes in the whole pragmatic knowledge gained using CMC and a traditional method. By using appropriate statistical means, the researchers found out that there is a significant difference in the pragmatic competence of both groups in the post-test in favor of the experimental group, therefore the hypothesis of the study which reads" CMC has a great effect on the pragmatic competence of FL learners" is confirmed.

It is obvious from Table 3 that the mean scores of the experimental group in the post-test were higher than those of the control group. The differences in this finding may be attributed to the method of teaching.

Table 3. Means and Standard Deviations of the Experimental and Control Groups on the Post-Tests

\begin{tabular}{ccccccc}
\hline Group & N & Mean & Std. & DF & T & Sig \\
\hline Control Group & 15 & 49.47 & 13.989 & \multirow{2}{*}{30} & 3.950 & 0.000 \\
Experimental Group & 17 & 68.88 & 13.774 & & & \\
\hline
\end{tabular}

Table 3 shows that there is a significant statistical difference between the performances of the two groups. This difference indicates that using web-cam chat in the English language teaching to undergraduate EFL has a positive effect on the pragmatic competence of the learners, where the mean score for the experimental group was 68.88 while for the control group was 49.47 .

Table 4. Means and Standard Deviations of the Experimental Group Students on Both the Pre and Post-Tests

\begin{tabular}{cccccc}
\hline Test & Mean & Std & T value & Df & Sig. \\
\hline Pre & 42.76 & 13.155 & 0.146 & 30 & 0.885 \\
Post & 68.88 & 13.774 & 3.950 & 30 & 0.000 \\
\hline
\end{tabular}

It is evident that the experimental group performed much better on the post-test than on the pre-test as shown in Table 4. This difference in the mean scores on the pre-test and post-test was statistically measured by using $\mathrm{T}$-test which showed a significant difference between the mean scores of the experimental group on the pre-test and post-test as a result of the effect of using CMC on students' pragmatic competence. To find out the amount of progress that each group had achieved during the period of the study, mean scores and standard deviations of the two groups were calculated as shown in Table 5 below.

Table 5. Means and Standard Deviations of the Two Groups in the Pre and Post-Tests

\begin{tabular}{cccccccc}
\hline Test & Group & N & Mean & $\begin{array}{c}\text { Std. } \\
\text { Deviation }\end{array}$ & T value & Df & Sig \\
\hline \multirow{2}{*}{ Pre } & Control & 15 & 42.07 & 13.828 & 0.146 & 30 & 0.885 \\
& Experimental & 17 & 42.76 & 13.155 & & & \multirow{2}{*}{ Post } \\
& Control & 15 & 49.47 & 13.989 & 3.950 & 30 & 0.000 \\
\hline
\end{tabular}


Table 5 shows the amount of progress each group had achieved. The experimental group got an increase of 26.12 scores in their mean score on the post-test compared with their mean score on the pre-test. On the other hand, the control group got an increase of 7.4 scores only in their mean scores on the post-test compared with their mean scores on the pre-test. In addition, the results indicate that there is a statistical impact of the web-cam chat on pragmatic competence, in which the experimental group got higher scores than the control group.

\subsection{Findings Related to the Second Question}

Question 2 is which pragmatic aspects of language did learners develop more as a result of using web-cam chat? These aspects include (discourse function, speech acts, speech function, degrees of formality, and politeness). To answer this question, One-way ANOVA was applied to the pragmatic aspects of language (discourse function, speech acts, speech function, degrees of formality, and politeness) for pre/post assessment. Tables 6 and 7 show that.

Table 6. The Pre-Post Test Results of Both Groups' Students in the Pragmatic Aspects of Language

\begin{tabular}{|c|c|c|c|c|c|c|c|c|c|}
\hline \multirow{2}{*}{$\begin{array}{l}\text { Aspects } \\
\text { of language }\end{array}$} & \multirow[b]{2}{*}{ Test } & \multicolumn{4}{|c|}{ Experimental group } & \multicolumn{4}{|c|}{ Control group } \\
\hline & & Mean & $\begin{array}{c}\text { Std. } \\
\text { Deviation }\end{array}$ & $\mathbf{F}$ & $\begin{array}{l}\text { Sig. } \\
(p)\end{array}$ & Mean & $\begin{array}{c}\text { Std. } \\
\text { Deviation }\end{array}$ & $\mathbf{F}$ & $\begin{array}{l}\text { Sig. } \\
(p)\end{array}$ \\
\hline Discourse & Pre & 7.24 & 2.333 & -13.322 & 0.000 & 7.13 & 2.560 & -3.055 & 0.000 \\
\hline function $20 \%$ & Post & 13.41 & 3.809 & & & 7.53 & 2.416 & & \\
\hline Speech & Pre & 10.65 & 3.605 & -12.676 & 0.000 & 10.47 & 3.461 & -13.360 & 0.000 \\
\hline function $20 \%$ & Post & 17.76 & 2.195 & & & 13.87 & 3.833 & & \\
\hline Speech acts & Pre & 8.53 & 3.243 & -21.231 & 0.000 & 8.47 & 2.997 & -10.693 & 0.000 \\
\hline $20 \%$ & Post & 16.65 & 2.783 & & & 9.87 & 3.114 & & \\
\hline Degrees of & Pre & 6.76 & 2.016 & -7856 & 0.000 & 6.60 & 2.131 & -10.583 & 0.000 \\
\hline formality $20 \%$ & Post & 8.88 & 2.848 & & & 7.93 & 2.219 & & \\
\hline Politeness & Pre & 9.59 & 3.043 & -13.420 & 0.000 & 9.40 & 3.355 & -5.245 & 0.000 \\
\hline $20 \%$ & Post & 12.18 & 3.486 & & & 10.27 & 3.240 & & \\
\hline Both groups & pre & 42.76 & 13.155 & & & 42.07 & 13.828 & & \\
\hline $\begin{array}{l}\text { students' Mean } \\
\text { score out of } \\
100 \%\end{array}$ & Post & 68.88 & 13.774 & -40.385 & 0.000 & 49.47 & 13.989 & -25.561 & 0.000 \\
\hline
\end{tabular}

Table 6 shows that:

1. There were significant differences in the experimental groups' performance of the pragmatic aspects of language (discourse function, speech acts, speech function, degree of formality, and politeness), where all the values of $\boldsymbol{f}$ on the post test is statistically significant in favor of post-test on all pragmatic aspects of language.

According to the results, it was clear that scores of the experimental group were better than those of the control group, and the level of the experimental group on the pragmatic aspects of language has improved after exposure to the authentic materials over eight weeks of 
chatting with native speakers of English while there was no improvement in the level of the control group. Therefore, web-cam chat has a positive effect on the pragmatic aspects of language.

Table 7. The Both Groups Students' Results in Each Pragmatic Aspect of Language on the Post-Test

\begin{tabular}{ccccccc}
\hline Aspects of language & Group & Mean & Std.Deviation & F & DF & Sig. $(\boldsymbol{p})$ \\
\hline Discourse function & Experimental & 13.41 & 3.809 & 5.130 & 30 & 0.000 \\
$\mathbf{2 0 \%}$ & Control & 7.53 & 2.416 & & & \\
& Experimental & 17.76 & 2.195 & 3.584 & 30 & 0.001 \\
Speech function 20\% & Control & 13.87 & 3.833 & & & \\
& Experimental & 16.65 & 2.783 & 6.506 & 30 & 0.000 \\
Speech acts 20\% & Control & 9.87 & 3.114 & & & \\
Degrees of formality & Experimental & 8.88 & 2.848 & 1.041 & 30 & 0.306 \\
$\mathbf{2 0 \%}$ & Control & 7.93 & 2.219 & & & \\
Politeness 20\% & Experimental & 12.18 & 3.486 & 1.598 & 30 & 0.120 \\
Mean score out of & Control & 10.27 & 3.240 & & & \\
$\mathbf{1 0 0 \%}$ & Experimental & 68.88 & 13.774 & 3.950 & 30 & 0.000 \\
\hline
\end{tabular}

Table 7 shows that:

1- There were significant differences in students' performance of the discourse function as one of main pragmatic aspects of language due to the use of web-cam chat, where $f$ value reached 5.130, at $\alpha \leq 0.000$ level. This indicates that there were significant differences due to the use of web-cam chat in favor of the experimental group mean 13.41, whereas the means for the control group reached 7.53.

2- There were significant differences in students' performance of the speech function as one of the main aspects of pragmatics due to the use of web-cam chat, where $f$ value reached 3.58, at $\alpha \leq 0.001$ level. This indicates that there were significant differences due to the use of web-cam chat in favor of the experimental group mean17.76, whereas the mean for the control group reached 13.87 .

3- There were significant differences in students' performance of the speech acts which is macrolinguistically regarded as one of main pragmatic aspects of language due to the use of web-cam chat, where $f$ value reached 6.506, at $\alpha \leq 0.000$ level. This indicates that there were significant differences due to the use of web-cam chat in favor of the experimental group mean 16.65, whereas the mean for the control group reached 9.87.

4- There were significant differences in students' performance of the degrees of formality due to the use of web-cam chat, where $f$ value reached 1.041, at $\alpha \leq 0.306$ level. This indicates that there were significant differences due to the use of web-cam chat in favor of the experimental group mean 8.88 , whereas the mean for the control group reached 7.93 . 
5- There were significant differences in students' performance of the politeness as one of main pragmatic aspects of language due to the use of web-cam chat, where $f$ value reached 1.598, at $\alpha \leq 0.120$ level. This indicates that there were significant differences due to the use of web-cam chat in favor of the experimental group mean 12.18, whereas the mean for the control group reached 10.27.

According to these results, it was clear that the scores of the experimental group were better than the control group on the pragmatic aspects of language that has improved after exposure to the authentic materials over eight weeks, while there was no improvement in the level of the control group. In addition, students' achievement in discourse function, speech function, speech acts, and politeness were better than other pragmatic aspects of language such as the degree of formality. In other words, students' scores in discourse function, speech function, speech acts, and politeness were better than other pragmatic aspects of language such as the degree of formality, where the mean scores of discourse function was 13.41 , speech function was 17.76 , speech act was 16.65 , and politeness was 12.18 , while the mean scores of degree of formality was 8.88 . Accordingly, web-cam chat had less effect on the pragmatic aspect of language related to degree of formality. According to the contemporary theories of contrastive linguistics, this result might be due to the wide gap between English and Arabic regarding this pragmatic aspect of language, because the wider the gap between L1 and L2 systems, the more errors students are expected to make, and the more difficulties they are expected to face Corder (1967).

Moreover, diagram 1 shows that students' performance was the best regarding the discourse function, speech acts, speech function, and politeness, whereas their performances regarding degree of formality was the worst.

Diagram 1 shows the means of the experimental group's performances in each pragmatic aspect of language.

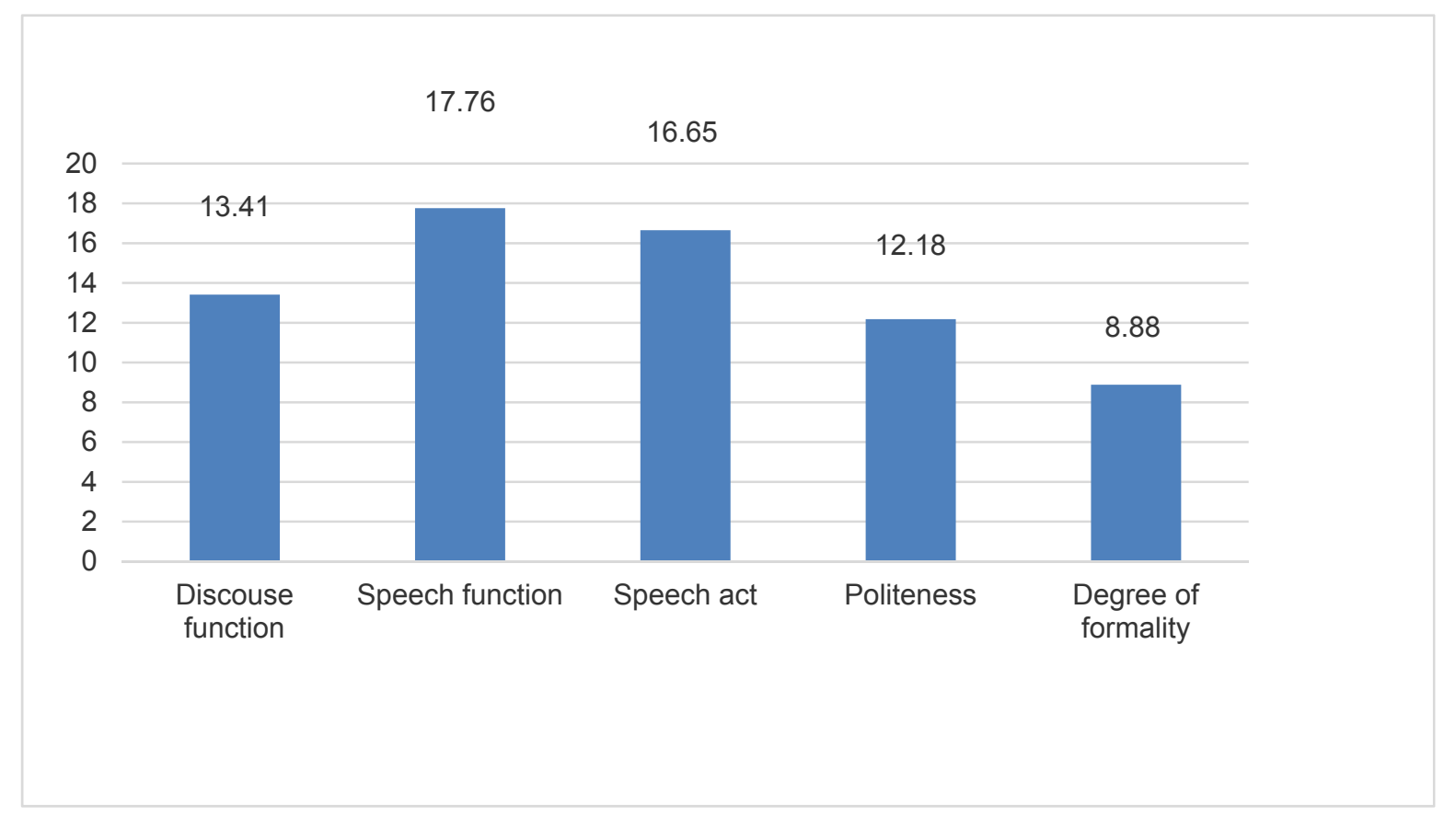




\section{Macrothink Institute ${ }^{\mathrm{TM}}$}

The findings of the present study indicated that students have developed their pragmatic knowledge over eight weeks of a semester through web-cam chat. At the beginning of the semester, students took a pre-test on the pragmatic aspects of language. At the end of the study, they sat to the same test (post-test) and scored statistically higher. This result confirms the hypothesis of the study which reads " web-cam chat has a positive effect on the learners' mastery of pragmatic aspects of language "

\section{Findings Related to the Third Question}

Question 3 reads " Are there any significant differences between the mean scores of the experimental and control groups in pragmatics due to skills (receptive vs. productive skills)? To answer this question, One-way ANOVA was applied for the means of the two groups on the tests (reading, writing, speaking, and listening) for pre/post test. Tables 8 and 9 show that.

Table 8. The Pre/Post-Test Results of Both Groups in Language Skills

\begin{tabular}{|c|c|c|c|c|c|c|c|c|c|}
\hline \multirow[b]{2}{*}{ Test type } & \multirow[b]{2}{*}{ Test } & \multicolumn{4}{|c|}{ Experimental group } & \multicolumn{4}{|c|}{ Control group } \\
\hline & & Mean & $\begin{array}{c}\text { Std. } \\
\text { Deviation }\end{array}$ & $\mathbf{F}$ & $\begin{array}{l}\text { Sig. } \\
(p)\end{array}$ & Mean & $\begin{array}{c}\text { Std. } \\
\text { Deviation }\end{array}$ & $\mathbf{F}$ & $\begin{array}{l}\text { Sig. } \\
(p)\end{array}$ \\
\hline Reading & Pre & 11.59 & 3.374 & -19.696 & 0.000 & 11.87 & 3.796 & -14.789 & 0.000 \\
\hline $25 \%$ & Post & 14.94 & 3.832 & & & 14.13 & 3.925 & & \\
\hline Writing & Pre & 10.29 & 3.405 & -16.090 & 0.000 & 10.20 & 3.406 & -29.103 & 0.000 \\
\hline $25 \%$ & Post & 12.59 & 3.411 & & & 13.87 & 3.292 & & \\
\hline \multirow{2}{*}{ Speaking 25\% } & Pre & 9.94 & 3.799 & -25.161 & 0.000 & 9.53 & 3.623 & -4.583 & 0.000 \\
\hline & Post & 20.24 & 3.930 & & & 10.13 & 3.623 & & \\
\hline Listening & Pre & 10.94 & 3.418 & -27.791 & 0.000 & 10.47 & 3.603 & -9.539 & 0.000 \\
\hline $25 \%$ & Post & 21.12 & 3.706 & & & 11.33 & 3.658 & & \\
\hline Both groups & Pre & 42.76 & 13.155 & & & 42.07 & 13.828 & & \\
\hline students' Mean & & & & -40.385 & 0.000 & & & -25.561 & 0.000 \\
\hline $\begin{array}{l}\text { score out of } \\
100 \%\end{array}$ & Post & 68.88 & 13.774 & & & 49.46 & 13.989 & & \\
\hline
\end{tabular}

Table 8 shows that:

1- There are significant differences for experimental groups' performance of the pragmatic aspects of language on the different skills (reading, writing, listening, and speaking) where all the values of $\boldsymbol{f}$ were statistically significant in favor of the experimental group on the post-test.

According to these results, it was clear that the scores of the experimental group were better than those of the control group, and the level of the experimental group in the language skills has improved a lot after exposure and interaction with native speakers of English over eight weeks, while there was less significant improvement in the level of the control group. So, web-cam chat has a positive effect on the students' language skills. 
Table 9. The Post-Test Results of Both Groups in Language Skills

\begin{tabular}{|c|c|c|c|c|c|c|}
\hline Test type & Group & Mean & Std.Deviation & $\mathbf{F}$ & DF & Sig. $(p)$ \\
\hline \multirow{2}{*}{ Reading $25 \%$} & Experimental & 14.94 & 3.832 & 0.588 & 30 & 0.561 \\
\hline & Control & 14.13 & 3.925 & & & \\
\hline \multirow{2}{*}{ Writing 25\% } & Experimental & 12.59 & 3.411 & -1.075 & 30 & 0.291 \\
\hline & Control & 13.87 & 3.292 & & & \\
\hline \multirow{2}{*}{ Speaking $25 \%$} & Experimental & 20.24 & 3.930 & 7.525 & 30 & 0.000 \\
\hline & Control & 10.13 & 3.623 & & & \\
\hline \multirow{2}{*}{ Listening $25 \%$} & Experimental & 21.12 & 3.706 & 7.498 & 30 & 0.000 \\
\hline & Control & 11.33 & 3.658 & & & \\
\hline Mean score out of & Experimental & 68.88 & 13.774 & 3.950 & 30 & 0.000 \\
\hline $100 \%$ & Control & 49.46 & 13.989 & & & \\
\hline
\end{tabular}

Table 9 shows that:

1- There were less significant differences due to the use of web-cam chat on the reading test, where $f$ value reached 0.588 , at $\alpha \leq 0.561$ level. This indicates that there were less significant differences in favor of the experimental group mean 14.94, and the mean for the control group reached 14.13.

2- There were less significant differences due to the use of web-cam chat on the writing test, where $f$ value reached -1.075, at $\alpha \leq 0.291$ level. This indicates that there were less significant differences in favor of the experimental group mean 12.59 , and the mean for the control group reached 13.87 .

3- There were high significant differences due to the use of web-cam chat on the speaking test, where $f$ value reached 7.525, at $\alpha \leq 0.000$ level. This indicates that there were significant differences in favor of the experimental group mean 20.24, whereas the mean for the control group reached 10.13 .

4- There were high significant differences due to the use of web-cam chat on the listening test, where $f$ value reached 7.498, at $\alpha \leq 0.000$ level. This indicates that there were significant differences in favor of the experimental group mean 21.12, whereas the mean for the control group reached 11.33.

It was clear that the achievements of the experimental group was better than those the control group, and the level of the experimental group in the listening and speaking skills improved after chatting with native speakers of English over eight weeks. Students' scores in the listening and speaking skills were better than the reading and writing skills, while there was less improvement in the level of the control group. Moreover, the experimental group students have developed a lot in listing and speaking skills, while the control group students have developed less in the reading and writing skills. Accordingly, it is unsurprising to find that the experimental group subjects were more able to explain their minds and feelings fluently, expressively, and amazingly. Accordingly, web-cam chat has a positive effect on improving the students' language skills such as listening and speaking skills. 
In addition, the findings of the present study indicate that students' scores of the English language skills have developed effectively in listening and speaking skills over eight weeks of a second semester through the use of CMC (web-cam chat). At the beginning of the semester, students took a pre-test on the pragmatic aspects which they acquired through web-cam chat during the semester. At the end of the study, they took the same test (post-test) and scored statistically higher. This result confirms the hypothesis of the study which reads " web-cam chat has a positive effect on the (receptive vs. productive skills) of the learners "

Results suggest that web-cam is found to offer a great opportunity in the acquisition of the pragmatic aspects of language due to the method of teaching. Moreover, the learners developed their pragmatic aspects of the language as a result of using web-cam chat; these aspects include (discourse function, speech acts, speech function, degrees of formality, and politeness). Furthermore, web-cam chat affects participants' performance more positively in the listening and speaking skills than the reading and writing skills.

\section{Discussion}

This section tackles the following sub-sections: Discussion of the results of the first question, discussion of the results of the second question, discussion of the results of the third question, conclusions, and recommendations.

\subsection{Discussion of the Results of the First Question}

The first question investigated if there were any statistical significant differences between the mean scores of the experimental and control groups in pragmatics due to the method of teaching (web-cam chat CMC vs. regular communicative method).

After having content analysis of the intentionally prescribed textbook used in teaching the intended course (Conversation Skills), the researchers found out that it is to some extent emptied of the pragmatic aspects of language. Accordingly, the researchers did his best with the help of a team of experts in curriculum and instruction to select material that achieve the goal of the study, that is the effect of using web-cam chat on EFL students' pragmatic competence. This new orientation is decided to give both groups a chance to learn the pragmatic aspects of English whether traditionally or innovatively.

According to the findings of this study, web-cam chat is found to offer a great opportunity in teaching the aspects of pragmatics implicitly. Students achieved better results on the listening and speaking test in a web-cam chat environment more than the other group that was taught the pragmatic aspects in a regular communicative method without using any technology.

More importantly, the researchers observed that using web-cam chat is found to add fun to the process of learning and teaching; students enjoyed spending long time a day in front of the computer screen practicing language. Communication about computers helped students in changing their attitudes, ideas, and thoughts towards the English class. This means that they are no longer shy, reluctant, afraid, or fear committing, mistakes, and errors. This might be attributed to many major factors; enhancing language learners' communicative competence, 
developing communicative language skills, feeling refreshed when they get rid restrictions of their classroom and go to computer laboratory which may incredibly reduce English period's monotony, and changing students' state stimulates their abilities and encourage them to spend more time in front of the computer screen in practicing language skills. These results are also in harmony with what is reported by Cheng, Krunwiede \& Shen (2009) who compared online audio group discussion with face-to-face (traditional method) where the results revealed that participants were more willing to express their opinions, ideas, and thoughts. Compared with online typing, the use of speaking leads participants to have greater satisfaction and self-disclosure. Online audio chat produces results that are superior to those that can be achieved in the context.

In addition, other interpretations and observations of the researchers could be the relaxing atmosphere and satisfaction the student encounters when using online web-cam chat in computer. Moreover, some students enjoyed using web-cam chat as teaching aids from which they always learn a lot. Thus, students received information from each other cooperatively via web-cam such as audio, web-cam, email, and voice chat in a more relaxing atmosphere than being received from teachers via a regular communicative method. During the process of communication, students were away from direct and strict instructions. Interestingly, students were more willing to receive information from web-cam than from teachers because web-cam chat does not worry information when they make mistakes. These results are also in harmony with what are reported by Kern (1995) who suggested that CMC could reduce learners' anxiety and increase their motivation, thus resulting in more active participation from quiet learners who usually choose not to participate in the whole oral discussions in the class. Also, this finding goes with what is reported by Kitade (2000) who reported that CMC has a positive effects on the classrooms language. She observed that it facilitates collaborative, relating atmosphere, and comprehensible interaction while providing individual learners an opportunity for learner-centered interaction.

Furthermore, this result is consistent with what was reported by Satar \& Ozdener (2008) who investigated the use of two synchronous computer-mediated communication tools; text and voice chat on speaking proficiency and anxiety. The results showed that the speaking proficiency of both experimental groups increased, whereas there was a decrease in the level of anxiety for the text chat groups. Moreover, this result is also in harmony with what is reported by Sahin (2009) who reported that learning in CMC environment develops EFL learners' ability in vocabulary acquisition. In addition, this finding is also in line with what is reported by Shang (2007) who found out that computer-based exchanges with peers at least four times have a greater improvement on the participants' writing performance. Also, this finding is in harmony with what is reported by Cummings (2004) who observed that in the online course for EFL writers, students' essays are more developed, more unified, more coherent, or generally more free from error than those of their face-to-face counterparts.

On the other hand, these findings are against what is reported by AL-Sa'di and Hamdan (2005) who described the main linguistic features of English used in real-time Internet chat channels. They found that sentences are characteristically short and simple, many words are 
distorted and truncated in familiar and unfamiliar way, abbreviations and acronyms are widespread and taboo words are likely to occur in most chat sessions.

\subsection{Discussion of the Results of the Second Question}

The second question sought to determine which pragmatic aspects of language learners developed more as a result of using web-cam CMC chat. These aspects include (discourse function, speech acts, speech function, degrees of formality, and politeness). The findings of the study revealed that using web-cam CMC chat in a language learning environment has numerous benefits; including promoting meaningful human interactions that can foster the learning process, cultivating social relationships, and prepare the relaxing environment. Moreover, these findings are in line with the results of many studies that discuss the importance of using web-cam chat in teaching the pragmatic aspects of language, such as Salaberry (1996), and Cooper and Selfe (1990). Furthermore, it is an excellent medium for cultivating social relationships within or across classrooms. Besides, these results are also in harmony with what are reported by Salaberry (1996), and Warschauer (1996) who provided an environment that fosters equal participation. Additionally, they explored what learners can proceed at their own pace, which helps reduce anxiety. More importantly, the process of communication via web-cam discussions helps learners develop the connection between thinking and writing. By the same token, the result of the present investigation confirms the merits of applying web-cam CMC chat to educational settings and provide evidence that web-cam is a potential channel for helping learners recognize the pragmatic aspects of the target language.

In addition, the findings indicated that learners improved a lot. The terms of four grading components; the ability to use the correct speech act, to provide appropriate expressions, to provide enough information to accomplish the task, and to use the appropriate level of politeness. Such progress occurred after eight weeks of pedagogical intervention. However, since the four components were highly correlated, it was hard to suggest the order of developing the four components. So, these results are also in harmony with what is reported by Chia-Ning Liu (2007). Moreover, this also answered the second research question, regarding whether there was an order for developing the five pragmatic aspects.

According to the abundant literature on the effects of instructional technology on both second and foreign language learning in general, and the benefits of instructional technology on the development of students' pragmatic competence, these results are in harmony with the results that are reported by Mirzaei, and Esmaeili (2013). Also, these results go with other studies such as Alco,'n (2005); and Tateyama (2008).

Besides, the role of web-cam CMC chat provided learners with the opportunity to interact with the target-language community and practice the pragmatic forms or features of the target language. By using web-cam by the experimental group, it was confirmed that web-cam had a great effect on EFL students' pragmatics competence. Compared to the conventional method, the web-cam chat environment was more practical and useful in facilitating daily communication. So, these results are in line with the results of studies such as Schmidt, 
(1993), and Chia-Ning (2007) that discussed the importance of CMC in teaching the pragmatic forms of the target language.

More importantly, the researchers found out that the results of the study suggested that teaching pragmatics through web-cam $\mathrm{CMC}$ is a potentially beneficial delivery mechanism of pragmatics content. web-cam learning has provided students with the opportunity to acquire pragmatic aspects of the target language using an authentic environment. Participants shared the target pragmatic knowledge, and their experiences. In addition, participants from Jordan experienced authentic learning through the use web-cam with native speakers of English. This demonstrated the power of collaborative learning and peer interaction. These results are consistent with what was reported by Chia-Ning Liu (2007).

In addition, literature on web-cam chat has suggested that decentralized, learner-center, and democratic on-line environment promote development of critical thinking, reflective skills, and provide the students with the opportunity to acquire the target pragmatic knowledge. These results are in harmony with what was reported by Chia-Ning Liu (2007). Moreover, previous studies have demonstrated the numerous merits of applying web-cam into language learning and teaching classrooms. First, web-cam chat tends to create more equal participation than the traditional method (face-to-face discussion), resulting in a more fully collaborative interaction, and acquire the pragmatic aspects of language. More importantly, web-cam chat allows learners to better notice the input from others' messages and incorporate that input into their own message, thus expanding opportunities for the learning of new linguistic forms and rules. These results are in harmony with what was reported by Warschauer (1996).

According to the findings of this study, the researchers support the idea of including web-cam chat in the language learning settings because learners do not acquire appropriate use of the target language on their own. Furthermore, the role of web-cam chat in learning pragmatic aspects becomes even more important in foreign-language classrooms, because pedagogical intervention is the primary access by which learners explore the target language. Moreover, learning English is more difficult in an EFL learning environment compared to English as a second language environment because EFL learners do not have the opportunity to interact with native speakers of the target language as ESL learners do. Therefore, the role of web-cam chat and the responsibility of language educators become crucial to learners' acquisition of the target language aspects of pragmatics. A language educator's responsibility is to remind learners that grammatical knowledge alone does not ensure language proficiency but that proficiency comes from knowing and implementing linguistic rules found in language use. In addition, language educators have to provide implicit web-cam chat in their FL class. As a result, learners have the opportunity to "notice" certain pragmatic features as they build on their existing pragmatic knowledge and move toward L2 fluency. These results are consistent with what was reported by Chia-Ning Liu (2007) who explored that learners have an opportunity to observe the pragmatic aspects of language through the implicit web-cam chat in foreign-language classrooms. 


\subsection{Discussion of the Results of the Third Question}

The third question investigated if there were any statistical significant differences between the mean scores of the experimental and control groups in pragmatics due to skills (receptive vs. productive skills). The finding of the study revealed that students acquired the (speaking and listening) skills in a web-cam chat environment more efficiently and effectively. This might refer to many factors. Firstly, students found it is interesting to express their opinions in speaking because they would not be told about every mistake they committed in speaking. Moreover, the main concern or purpose of speaking is conveying the message to the target group regardless of how many mistakes are committed in transferring the message. These results are in line with Satar \& Ozdener (2008). In addition, the role of videoconferencing technology helped to develop listening comprehension skills where the student engaged in a more multi-modal approach to learning and teaching the target language. However, these results go with the results that are reported by Glisan et al, (1998). Moreover, web-cam chat also developed students' performance in listening skills. Besides, this may be attributed to the fact that students might concentrate more, benefit from their mates, and discover their errors and mistakes in a web-cam chat environment.

After interpreting and analyzing the row scores of both group subjects, the researchers found that the experimental group students have developed a lot in the listening and speaking skills. This might be due to the effect of the web-cam chat through which the experimental group students interacted a lot with native speakers of English. Accordingly, it is unsurprising to find that the experimental group's subjects were more able to explain their minds and feelings fluently, expressively, and amazingly.

Furthermore, this finding is in line with what is reported by Hlas et al. (2008). They argued that EFL learners participated more equally in a discussion in a web-cam chat environment. Therefore, the role of web-cam chat provided learners with the opportunity to interact with the target-language speakers and practice speaking skills through the use of web-cam chat. Moreover, McAlister et al. (2004) also agreed with these findings as they noticed that the argumentation process through synchronous online peer discussion is more coherent, varied, deeper, and extended compared with face-to-face discussion.

In addition, this finding might be attributed to the fact that students could communicate with other classmates in the Internet chat that is a relaxing atmosphere, which might help them to develop their fluency and accuracy in speaking. However, these findings are in line with Xiao (2007) who explored that participants who used Internet-based desktop videoconferencing in the experimental group outperformed the L2 students in the control group throughout the treatment in terms of fluency and accuracy. More importantly Satar \& Ozdener (2008) lent support to these findings and reported that synchronous CMC enriches speaking proficiency levels of the students in the voice chat group and reduces language anxiety levels of the students in both the text and voice chat groups.

Furthermore, this result is also in harmony with what is reported by Blake (2009) who discovered that the Internet chat group demonstrated higher average gain scores on all five measures when compared to the control group and higher average on all measures when 
compared to the face-to-face group for improving oral fluency in the second language. Moreover, the results showed that learners who used the Internet chat method could develop students' performance in speaking skills, and it developed their speaking skills more than those who simply attended face-to-face interaction lessons without using this method.

In addition, these findings are in line with Jaya (2008) who reported that the voice modes of Skype are said to be helpful in language learning, especially the speaking skill. Skype provided learners with the opportunity to interact with target-language speakers. Moreover, it helped to develop students' proficiency. Finally, the results are in line with Payne \& Whitney (2002) who reported that L2 oral proficiency can be indirectly developed through the chat room interaction in the target language.

More importantly, CMC could enhance language learners' communicative language skills. Audio-visual chats have been found to offer a number of benefits for the development of L2 oral skills where the learner engaged in debate with native speakers using CMC. Hence, these results are in line with Sun, (2009) and Zhao (2003). In addition, these technologies can encourage students' participation and foster extensive oral production in the target language. These results go with the results that are reported by Beauvois (1997) and Rosen (2009), who explored the role of technology to develop the students' oral production. Moreover, these technologies can enhance L2 motivation; reduce anxiety, effective language learning, and learner autonomy. Besides, these results are in line with the results reported by Sun (2009) and Beauvois (1998).

In addition, $\mathrm{CMC}$ online listening played a very important role to activate more learning resources than is the case with text-based tasks, and adopted a deep integrative approach to learning. Moreover, CMC online listening tasks in L2 could lead to greater retention of information and vocabulary. This greater retention of information and vocabulary can lead to noticeable cross modality gains. However, these results are in line with the results reported by Absalom and Rizzi (2008) who aimed at comparing the effects of online listening and online text-based tasks. They concluded that online listening tasks in L2 required students to activate more learning resources than is the case with text-based tasks and adopted a deep integrative approach to learning.

\section{Conclusion}

It could be concluded that the use of CMC is very important because it might help students learn the pragmatic aspects of language. CMC materials containing native speakers' voices should be exploited as much as possible. Accordingly, universities should be equipped with such materials. In addition, the CMC could break down the psychological walls of the classroom and give access not only to diverse sources but also to opportunities for genuine communication, collaborative online, develop language skills, reduce anxiety, and increase oral discussion Kern, (1995).

In addition, $\mathrm{CMC}$ presents the pragmatic aspects of language, particularly if learners have had little or no contact with native speakers of English. Students could see as well as hear 
what is being said since CMC is much closer to "real life". The visual element is attractive and it gives a natural context for practicing the two language skills such as listening and speaking. One characteristic of CMC is that it presents language in the context of life. More importantly, it shows students how language is used naturally in realistic settings. Students can see facial expressions, gestures, and whether the speaker is hesitant or not about a particular subject. They could observe the body language of a situation, how far apart people stand, how the characters react to emotional situations information that is difficult to get from a book or an audio tape component of the foreign language, and how EFL learners interact with the English language speakers (Cifuentes and Shin, 2003).

Finally, web-cam chat has a positive effect on the EFL undergraduate learners' pragmatic competence since language cannot be taught without its pragmatic aspects. Accordingly, the pragmatic competence should be highly considered in EFL classes.

The following conclusions could be derived from this study:

1. Internet web-cam chat activities could be highly supportive to the learning of pragmatic aspects, and the speaking, listening skills.

2. Learning through web-cam chat is more permanent due to the use of various tools such as sound, text, cameras, microphones and computer screens.

3. Web-cam chat enables the individual to advance according to his own learning speed by taking into the consideration the characteristics of the individual.

4. The educational environments in which Internet web-cam chat applications are realized in the classroom are highly motivating environments for success and language learning, especially learning the pragmatic aspects of language, and productive skills.

Finally, according to the researchers' experience as a foreign language student, teacher, and researcher. In addition, according to what is stated in related literature as well, the researchers might be allowed to hypothesize that students' lack of knowledge and weakness might be due to the following:

Inappropriateness of the teaching method, insufficiency in qualification of teachers, interference of the learners' native language ,don't prepare better learning environment ,lack of use technology such as web-cam, and the material of instruction itself.

\section{Recommendations}

The following recommendations could be adopted in the area of using web-cam chat in helping students to develop their pragmatic aspects of language, and communication skills. According to the results of this study, the researcher suggested a set of recommendations.

It is important, therefore, to encourage teachers to use CMC (web-cam chat) in labs, and classroom because web-cam chats can do what teachers cannot; they can bring the real world 
into the classroom. The CMC (web-cam chats) are powerful medium but they are not an end in themselves. Moreover, they are teaching aids and can add a further dimension than of sight and sound to the teacher's existing repertoire of aids and materials.

\section{Acknowledgement}

My full indebtedness is for my student who were very cooperative and helpful throughout this study.

Special thanks to the team of examiners for their unexhausted efforts.

\section{References}

Abe, Y. (2011). The effects of computer-mediated communication on Japanese EFL Learners' English Proficiency. TCC Worldwide Online Conference, 2011(1), 169-185.

Absalom, M., \& Rizzi, A. (2008). Comparing the outcomes of online listening versus online text-based tasks in university level Italian L2 study. Re CALL, 20(1), 55- 66. http://dx.doi.org/10.1017/s0958344008000517

Alco'n, E. (2005). Does instruction work for learning pragmatics in the EFL context? System, 33, 417-435. http://dx.doi.org/10.1016/j.system.2005.06.005

ALsa'di, R., \& Hamdan, J. (2005). Synchronous online chat "English: Computer-mediated communication. World English, 409-424. http://dx.doi.org/10.1111/j.0883-2919.2005.00423.x

Bachman, L. (1990). Fundamental considerations in language testing. Oxford: Oxford University Press.

Bachman, L., \& Plamer, A. (1982). Language testing in practice: Design and developing useful language tests. Oxford: Oxford University Press.

Bardovi-Harlig, K., \& Hartford, B. (1991). Saying "No": Native and nonnative rejections in English. In L. F. Bouton \& Y. Kachru. (Eds.), Pragmatics and Language Learning, 487-521.

Bataineh, A. (2014). The effect of teaching literature on EFL students' pragmatic competence. Journal of Education and Practice, ISSN 2222-1735 (Paper) ISSN 2222-288X (Online).

Beauvois, M. (1997). Computer-mediated communication (CMC): Technology for improving speaking and writing. In M. D. Bush, \& R. M. Terry (Eds.), Technology Enhanced Language Learning (pp.165-184). Lincolnwood, IL: National Textbook Company.

Beauvois, M. (1998). Conversations in slow motion: Computer-mediated communication in the foreign language classroom. The Canadian Modern Language Review, 54(2), 198217. http://dx.doi.org/10.3138/cmlr.54.2.198 
Billmyer, K. (1990). "I really like your life style": ESL learners learning how to compliment. Penn Working Papers in Educational Linguistics, 6, 31-48.

Blake, Ch. (2009). Potential of text based internet chats for improving oral fluency in a second language. Modern Language Journal, 93(2), 227-240. http://dx.doi.org/10.1111/j.1540-4781.2009.00858.x

Bouton, L. F. (1994). Conversational implicature in the second language: Learned slowly when not deliberately taught. Journal of Pragmatics, 22, 157-67. http://dx.doi.org/10.1016/0378-2166(94)90065-5

Canale, M., \& Swain, M. (1980). Theoretical bases of communicative approaches to second language teaching and testing. Applied Linguistics, 1(1), 1-47. http://dx.doi.org/10.1093/applin/1.1.1

Cheng, C.; Krumwiede, D., \& Sheu, C. (2009). Online audio group discussions a comparison with face-to-face methods. International Journal of Market Research, 51(2), 219-241. http://dx.doi.org/10.2501/S1470785309200438

Chia-Ning Lui, B. (2007). The effect of pedagogical intervention and technology on the development of EFL learners' realization of "request". Published Dissertation.

Chun, D. (1998). Using computer networking to facilitate the acquisition of interactive competence. System, 22(1), 17-31. http://dx.doi.org/10.1016/0346-251X(94)90037-X

Cooper, M., \& Selfe, C. (1990). Computer conferences and learning: Authority, resistance, and internally persuasive discourse. College Engl 52(8), 847-869. http://dx.doi.org/10.2307/377388

Crystal, D. (1997). A dictionary of linguistics and phonetics (4th edition.). Cambridge, MA: Blackwell.

Cumming, M. (2004). Because we are shy and fear mistaking: CMC with EFL writers. Journal of Basic Writing, 23(2), 23-48.

D’Ambra, J., Rice, D., \& O’Connor, M. (1998). Computer-mediated communication and media preference: An investigation of the dimensionality of perceived task equivocability and media richness. Task Behaviour and Information Technology, 17, 164-174. http://dx.doi.org/10.1080/014492998119535

Darhower, M. (2002). Interactional Features of Synchronous Computer-Mediated Communication in the Intermediate L2 Class: A Sociocultural Case Study. CALICO Journal, 19(2), 249-277.

Eslami, Z. (2005). Raising the pragmatic awareness of language learners. ELT Journal, 59 (2), 199-208. http://dx.doi.org/10.1093/elt/cci039

Eslami-Rasekh, Z., Eslami-Rasekh, A., \& Fatahi, A. (2004). Using metapragmatic instruction to improve advanced EFL learners pragmatic awareness. TESL EJ, 8(2), 1-12.

Fukuya, Y. (1998). Consciousness-raising of downgraders in requests. Paper presented at second language research forum, University of Hawaii, Manoa, October. 
Glisan, G., Dudt, K., \& Home, M. (1998). Teaching Spanish through distance education: Implications of a pilot study. Foreign language Annals, 31, 48-66. http://dx.doi.org/10.1111/j.1944-9720.1998.tb01332.x

Greenfield, P., \& Subrahanayam, K. (2003). Online discourse in a teen chat room: New codes and new modes of coherence in a visual medium. Journal of Applied Developmental Psychology, 24(6), 713-738. http://dx.doi.org/10.1016/j.appdev.2003.09.005

Hlas, A., Schuch, K., \& ALESSI, S. (2008). Native and non-native speakers in online and face-to-face discussion: Leaving the playing field. Educational Technology System, 30(4), 337-373. http://dx.doi.org/10.2190/ET.36.4.b

House, J. (1996). Developing pragmatic fluency in English as a foreign language: Routine and metapragmatic awareness. Studies of Second Language Acquisition, 18, 225-252. http://dx.doi.org/10.1017/S0272263100014893

Jaya, R. (2008). Skype voice chat a tool for teaching oral communication. Language in India, $8(12), 9-9$.

Kasper, G. (1997). Can pragmatic competence be taught? (NetWork \#6). Honolulu: University of Hawaii, Second Language Teaching \& Curriculum Center. Retrieved November 2004 from http://nflrc.hawaii.edu/NetWorks/NW06/default.html

Kern, R. (1995). Restructuring classroom interaction with networked computers: Effects on quality and characteristics of language production. Modern Language Journal, 79(4), 457-476. http://dx.doi.org/10.1111/j.1540-4781.1995.tb05445.x

Kitade, K. (2000). L2 learners' discourse and SLA theories in CMC: Collaborative interaction in Internet chat. Computer Assisted Language Learning, 13, 143-166. http://dx.doi.org/10.1076/0958-8221(200004)13:2;1-D;FT143

Kubota, M. (1995). Teachability of conversational implicature to Japanese EFL learners. IRLT Bulletin, 9, 35-67.

McAliester, S., \& Ravenscroft, A. (2004), Scanlon, E. Combining interaction and context design to support collaborative argumentation using a tool for synchronous computer-mediated communication. Journal of Computer Assisted Learning, 20, 194. http://dx.doi.org/10.1111/j.1365-2729.2004.00086.x

Means, B., \& Roschelle, J. (2010). An overview of technology and learning. International Encyclopedia of Education, $8(3), \quad 1-10$. http://dx.doi.org/10.1016/b978-0-08-044894-7.00762-4

Mirzaei, A., \& Esmaeili, M., (2013). The Effects of Planned Instruction on Iranian L2 Learners' Interlanguage Pragmatic Development. Iranian Journal of Society, Culture \& Language, (1), 2322-4762.

Olshtain, E., \& Cohen, A. (1990). The learning of complex speech act behavior. TESL Canada Journal, 7, 45-65. 
Payne, J. \& Whitney, P. (2002). Developing 12 oral proficiency through synchronous CMC: output, working and Interlingua development. Calico Journal, 20(1), 32.

Rose, K. R. (1994). On the validity of discourse completion tests in non-Western contexts. Applied Linguistics, 15, 1-14. http://dx.doi.org/10.1093/applin/15.1.1

Rose, K. R. (2005). On the effects of instruction in second language pragmatics. System, 33(3), 385-399. http://dx.doi.org/10.1016/j.system.2005.06.003

Rose, K., \& Kwai-fun, C. (2001). Inductive and deductive teaching of compliments and compliments responses. In G. Kasper., \& K. Rose. (Eds.), Pragmatics and language teaching, (pp. 145-170). Cambridge: Cambridge University Press. http://dx.doi.org/10.1017/cbo9781139524797.013

Rosen, L. (2009). Reaching students: A hybrid approach to language learning. In R. Oxford \& J. Oxford (Eds.), Second language teaching and learning in the Net Generation (pp. 64-84). Honolulu: University of Hawai'i, National Foreign Language Resource Center.

Sahin, M. (2009). Second language vocabulary acquisition in synchronous computer-mediated communication. Eurasian Journal of Educational Research, 34, 115-132.

Salaberry, R. (1996). The development of past tense verbal morphology in classroom L2 Spanish. Applied Linguistics, 20, 151-178. http://dx.doi.org/10.1093/applin/20.2.151

Satar, M., \& Ozdener, N. (2008). The effect of synchronous CMC on speaking proficiency and anxiety: Text versus voice chat. The Modern Language Journal, 92(4), 595-613. http://dx.doi.org/10.1111/j.1540-4781.2008.00789.x

Schavo, T. (2011). Effect of technology on our lives. Language Learning \& Technology, 9(3), 146-163.

Schmidt, R. W. (1993). Awareness in second language acquisition. Annual Review of Applied Linguistics, 13, 206-226. http://dx.doi.org/10.1017/S0267190500002476

Shang, H. (2007). An exploratory study of E-mail application on FL writing performance. $\begin{array}{llll}\text { Computer Assisted Language } \quad \text { Learning, } & \text { 20(1), }\end{array}$ http://dx.doi.org/10.1080/09588220601118479

Shih, Y.C.D., \& Cifuentes, L. (2003). Taiwanese intercultural phenomena and issues in a United States-Taiwan telecommunications partnership. Educational Technology Research and Development, 51(3), 82-90. http://dx.doi.org/10.1007/BF02504555

Sun, Y.-C. (2009). Voice blog: An exploratory study of language learning. Language Learning \& Technology, 13(2), 88-103.

Tateyama, Y. (2001). Explicit and implicit teaching of pragmatic routines. In K, Rose \&G, Kasper (Eds.). Pragmatics in language teaching (pp. 200-222). Cambridge: Cambridge University Press. http://dx.doi.org/10.1017/CBO9781139524797.015 
Tateyama, Y., Kasper, G., Mui, L., Tay, H., \& Thananart, O. (1997). Explicit and implicit teaching on pragmatics routines. In L. Bouton., (Ed.), Pragmatics and language learning, monograph series, 8, 163-178.

Wang, Y., \& Chen, N. (2009). Criteria for evaluating synchronous learning management systems: Arguments from the distance language classroom. Computer Assisted Language Learning, 22(1), 1-18. http://dx.doi.org/10.1080/09588220802613773

Warschauer, M. (1996). Computer-Mediated collaborative Learning: Theory and Practice. Modern Language Journal, 81(4), 470-481. http://dx.doi.org/10.1111/j.1540-4781.1997.tb05514.x

Wildner-Bassett, M.E. (1994). Improving pragmatic aspects of learners' interlanguage. Tubingen: Gunter Narr Verlag.

Xia, Y. (2006). Computer-Mediated Communication Discourse in students' classroom writing. Ohio Communication Journal, 44, 109-124.

Xiao, M. (2007). An empirical study of using internet-based desktop videoconferencing in an EFL setting. Unpublished Ph. D Theses, College of Education, Ohio University, Ohio.

Ying, Z., \& Maria, A. (2010).Negotiation of meaning between non-native speakers in text-based chat and videoconferencing. US-China Education Review, 7(5), 12-26.

Yule, G. (2000). Pragmatics. Oxford: OUP.

Zeiss, E., \& Christiania, L. (2005). The role of analyzing computer-mediated communication on enhancing cultural awareness. Computer Assisted Language Learning, 18(3), 151-169. http://dx.doi.org/10.1080/09588220500173310

Zha, S., Kelly, P., Park, M., \& Fitzgerald, G. (2006). An Investigation of Communicative Competence of ESL Students Using Electronic Discussion Boards. Journal of Research on Technology in Education, 38(3), 349-367. http://dx.doi.org/10.1080/15391523.2006.10782464

Zhao, Y. (2003). Recent developments in technology and language learning: A literature review and meta-analysis. CALICO Journal, 21(1), 7-27.

Zsuzsana, I. (2010). Form Theory to Practice: Intercultural CMC in the L2 Classroom. Online include journal name not publisher, 13(2), 143-166.

\section{Copyright Disclaimer}

Copyright for this article is retained by the author(s), with first publication rights granted to the journal.

This is an open-access article distributed under the terms and conditions of the Creative Commons Attribution license (http://creativecommons.org/licenses/by/3.0/). 